\title{
Peranan Keluarga Hindu Dalam Mengantisipasi
}

\section{Perpindahan Agama}

\author{
Oleh : \\ I Ketut Sudarsana \\ Institut Hindu Dharma Negeri Denpasar

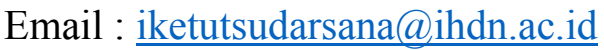

Pembentukan keluarga sehat sejahtera dan kekal peranan agama menjadi sangat penting, ini sesuai dengan rumusan sloka yang disuratkan dalam ajaran Veda yang berbunyi sebagai berikut:

Moksartham jagathita ya ca ithi dharma

Terjemahannya:

Bahwa agama atau dharma atau agama itu bertujuan untiuk membina kehidupan yang sejahtera dan bahagia secara lahir bathin. (Ngurah, 2001: 7)

Mencermati kutipan Pustaka Suci di atas, bahwa ajaran agama tidak cukup hanya diketahui dan dipahami saja, akan tetapi harus diamalkan oleh setiap anggota 
keluarga, sehingga kehidupan dalam keluarga benarbenar dapat mencerminkan suatu kehidupan yang damai yang dijiwai oleh ajaran dan tuntunan agama.

Keluarga adalah bentuk hidup bersama yang merupakan lembaga sosial terkecil dan terpenting, keluarga pada hakekatnya adalah lembaga pendidikan tempat belajar agama Hndu sehingga keluarga tersebut merupakan lembaga yang dapat menumbuhkan terjalinnya pengabdian dan teraturnya peningkatan hidup dalam mencapai tujuan hidupnya (Wiana, 1997 : 43)

Setiap anggota keluarga terutama orang tua dituntut untuk senantiasa bersikap dan berbuat sesuai dengan agama, sehingga dengan demikian diharapkan setiap anggota keluarga memiliki sifat dan bhudi pekerti yang luhur serta kepribadian mulia yang sangat diperlukan dalam kehidupan keluarga dan masyarakat. Untuk itu orang tua sangat perlu untuk mengetahuai betapa pentingnya pendidikan bagi setiap keluaraga dan khususnya bagi anak- anak karena hal itu sangat berpengaruh positip terhadap pertumbuhan dan 
perkembangan bhudi pekerti dan kepribadian mereka. Oleh sebab itu pendidikan agama perlu ditanamkan sedini mungkin terhadap anak - anak.

Keluarga adalah benteng yang utama dan kebahagiaan merupakan dasar dan pangkal utama dalam pergaulan masyarakat luas. Seorang ibu mengharapkan putra-putranya agar berguna bagi keluarga dan masyarakat serta dapat membentuk suatu kesatuan masyarakat yang teguh dan kuat.

Kebahagiaan atau kehancuran suatu keluarga sangat menentukan baik buruknya watak dan kepribadian seorang anak. Mengingat begitu pentingnya peranan keluarga dalam menentukan baik-buruknya watak seorang anak, maka hendaknya setiap orang tua dan anggota keluarga lainnya menyadari hal tersebut demi kebaikan si anak.

Jelaslah bahwa salah satu penyebab kegagalan pendidikan anak ialah kurangnya pendidikan dalam keluarga yaitu kelengahan anak dalam pergaulan yang terlalu bebas dan kelalaian orang tua dalam 
mengawasinya. Seperti dalam buku Putrasesana, disebutkan:

Ikang tanaya sewakanya tuwi yan tan inajaraken ulahnya ring hayu, kamudani yayahya, len liwat asihnya krana nika tan wuwusya, taya pwa pituturnya tadwa nikanang suta manasaring jana malah surud yasa nikang yayah dadi tekap ring panya wasani dosaning weak.

dosa kweh ketemu tekapnikang anak yapwan wineh lelana, mangka pwiki matang yaning tanaya yan dursusila septa danam, sang kspnya sihing yayah karaning tan lelanang swetamaja Terjemahannya:

Semua anak apabila tidak dituntun dengan membenarkan perbuatannya, hal itu adalah kesalahan orang tuanya, dan pula karena sangat cintanya kepada anaknya itu sehingga tidak pernah dinasehati yang menyebabkan kemuliaan sang anak tersesat dari kebenaran semua itu adalah merupakan kesalahan yang dibawa - 
bawa oleh kesalahan sang anak. Banyak dosa yang bias diperbuat oleh sang anak apabila ia dibiarkan liar dan sebaliknya banyak anak berkelakuan salah kalau ia terlambat mendapatkan pendidikan seharusnya demi kecintaan, sang bapak tidak membiarkan anaknnya liar tanpa batasan - batasan tertentu. (Sudarta, 1993: 56-57)

Pendidikan agama bila tidak ditanamkan sejak dini kepada anak akan dapat menimbulkan berbagai hal yang bersifat negatip di tambah dengan kemajuan zaman yang diiringi dengan kemajuan teknologi informasi yang sangat mempengaruhi kehidupan manusia baik dari segi ekonomi, sosial budaya maupun dalam kehidupan membentuk rumah tangga. Sehingga akan menimbulkan dampak positip dan negatif, dengan semakin meningkatnya jumlah perpindahan agama yang sering disebut dengan konversi agama dengan perbedaan suku, ras, budaya dan agama serta meningkat pula kasus penyelewengan, pemerkosaan dan kenakanalan remaja 
serta penggunaan obat terlarang. Dengan kemajuan teknologi di bidang informasi dan transportasi menyebabkan hubungan menjadi dekat dan lancar memungkinkan terjadinya konversi agama.

Berbicara mengenai perpindahan agama dapat dilihat dari pengertian konversi agama. Konversi berasal dari kata latin "conversion" yang berarti berpindahnya (berubahnya) seorang memeluk agama dari satu agama keagama yang lain (change from one state, or from one religion to another) berdasarkan arti tersebut konversi agama mengandung pengertian bertobat, berubah agama, berbalik pendirian terhadap ajaran agama atau masuk ke dalam agama. (Jalaluddin, 245)

Masalah pindah agama terutama lebih banyak terjadi pada kaum wanita, dimana dengan mudah bersedia untuk pindah agama setelah melakukan perkawinan dengan pria non Hindu. Kesediaan untuk pindah agama melalui perkawinan tersebut dipengaruhi oleh banyak faktor, seperti faktor; pendidikan, faktor ekonomi dan faktor lingkungan. Jika dilihat dari segi 
pendidikan agama Hindu baik dalam lingkungan keluarga, masyarakat, dan pemerintah, hingga saat ini belum memiliki sistem pendidikan agama Hindu yang representatif dan terpadu. Pengembangan pendidikan Agama Hindu di Indonesia dapat dikatakan belum memenuhi harapan umat Hindu. Hal ini disebabkan belum adanya lembaga pendidikan Hindu dari tingkat sekolah dasar sampai menengah yang berbasiskan Hindu, sehingga Pendidikan Agama Hindu pada lembaga pendidikan formal masih terbatas yakni hanya dapat alokasi waktu 2 (dua) jam pelajaran perminggu. Di samping itu tidak adanya pembelajaran pendidikan Agama Hindu di luar jam-jam sekolah seperti pasraman, atau sejenisnya yang khusus memberikan pendalaman pendidikan Agama Hindu.

Menurut Widyastana (2002:14) yang dimaksud dengan sekolah berbasis Hindu adalah sekolah yang di samping memberi pelajaran formal sesuai kurikulum yang telah ditetapkan pemerintah, dalam pelajaran agama hanya memberi pelajaran Agama Hindu saja bagi 
seluruh siswanya, menambahkan pelajaran-pelajaran/ ekstrakurikuler untuk meningkatkan pengetahuan dan keimanan mereka terhadap Tuhan serta mampu menerapkan nilai-nilai Hindu dalam kehidupan nyata.

Perpindahan agama yang mudah dengan alasan perkawinan menandakan bahwa pemahaman remaja belumlah matang, sehingga mudah terombang-ambing hanya dengan alasan cinta. Sehingga pendidikan nilainilai ajaran Agama Hindu yang sistematis dan berkelanjutan perlu dilaksanakan dan dikembangkan. Tujuannya adalah untuk meningkatkan pengetahuan, kecerdasan dan nilai keagamaan umat Hindu pada umumnya dan terutama bagi generasi muda Hindu pada khususnya. Guna mencapai tujuan tersebut dibutuhkan adanya lembaga pendidikan Agama Hindu baik formal maupun non formal sebagai wadah penyelenggara pendidikan nilai-nilai ajaran Agama Hindu. Lembagalembaga seperti itulah yang diharapkan dapat berperan secara aktif dalam upaya pembentukan insan-insan Hindu yang berbudi luhur. 
Tujuan utama dari pembelajaran pendidikan Agama Hindu adalah membentuk manusia berbudi luhur, susila, dan bijaksana, yaitu manusia yang dapat menghayati hakikat dari kehidupan yang penuh dengan tantangan dan penderitaan, manusia yang benar-benar mengetahui sebab-musabab sampai terjadinya penderitaan dan yakin bahwa betapapun bentuk penderitaan itu akan dapat dilenyapkan, karena telah diketahui jalan yang dapat membebaskan manusia dari penderitaan (Arsada, 2006:2).

Sedangkan fungsi pendidikan Agama Hindu berdasarkan kurikulum SMA Tahun 2004 adalah: (1) Penanaman nilai-nilai ajaran Agama Hindu yang dapat dijadikan pedoman hidup dalam mencapai kesejahteraan dan kebahagiaan hidup (moksarthan Jagadhita); (2) Pengembangan Sradha dan bhakti kehadapan Hyang Widhi (Brahman); (3) Pengajaran tentang ilmu pengetahuan keagamaan secara umum, sistem dan fungsinya; (4) Penyiapan kemampuan sikap mental siswa yang ingin melanjutkan studi ke jenjang yang 
lebih tinggi; (5) Mempersiapkan kematangan dan daya resistensi siswa dalam beradaptasi diri terhadap lingkungan fisik dan sosial; (6) Perbaikan kesalahankesalahan, kelemahan-kelemahan peserta didik dalam keyakinan dan pengamalan ajaran agama dalam kehidupan sehari-hari; (7) Pencegahan peserta didik dari hal-hal negatif yang diakibatkan oleh pergaulan di dunia luar.

Jika dalam kondisi masyarakat yang mayoritas mungkin masalah perpindahan agama tidak begitu mengemuka, tetapi pada kondisi masyarakat yang minoritas hal ini sudah menjadi persaingan/kompetisi terselubung. Terutama dalam meningkatkan generasi muda yang memiliki srada dan bhakti. Kasus perpindahan agama akan lebih meruncing lagi ketika pemahaman terhadap ajaran agama hanya mengandalkan pemahaman agama "gugon tuwon" yang menyebabkan di suatu sisi timbul gejala - gejala yang dapat memudarkan nilai filosofis Hindu. 
Kasus perpindahan agama saat ini sudah tidak bisa dipandang sesuatu yang biasa, mengingat adanya pergeseran kepercayaan kepada ajaran agama, dimana karena kelakuan beberapa orang yang berpindah agama menyebabkan orang lain ikut terpengaruh.

Hal-hal seperti ini sangat mengkhawatirkan bagi perkembangan Agama Hindu selanjutnya, dimana masyarakatnya merupakan masyarakat heterogen atau memiliki tingkat kemajemukuan yang tinggi. Kasus perpindahan agama sangat sering terjadi terutama yang melibatkan umat beragama Hindu 